\title{
DIFFERENTIALS IN HOUSING QUALITY IN LAGOS PERIPHERAL SETTLEMENTS
}

\author{
Adedire Funmilayo $M^{*}$ \\ Adegbile Michael $* *$
}

\begin{abstract}
Housing quality differs within neighbourhoods in Lagos peripheral settlements, due to internal and external factors. This study examines differentials in housing quality in Lagos's peripheral settlements and the factors responsible. Primary data was sourced through structured questionnaires, interviews and observation schedules administered through field survey in study areas. Two stage cluster sampling techniques were adopted for determining the sample size. Firstly, using a purposive sampling, to reduce cost and avoid repetitions, clusters of sixteen and eighteen settlements in Ibeju-Lekki and Ikorodu peri-urban settlements were selected respectively. Secondly, three hundred seventy and three hundred eighty four housing units were selected randomly from the selected housing clusters in Ibeju-Lekki and Ikorodu peripheral settlements respectively. Data analysis was done using statistical analysis to generate frequencies and percentages of responses on socio-economic profile, access to services and households' perception on neighbourhood quality, internal dwelling quality, external dwelling quality and building materials in the study area. Data processing and analysis for this study were carried out using the Statistical Package for Social Sciences (SPSS) for analysis of the quantitative data. Findings show differentials in the housing developments in the study areas due to various socioeconomic attributes, building materials used and the state government policy on infrastructure development. It is recommended that a data base of demography and the socioeconomic composition of the residents is needed, as this may help to know the infrastructural demand and also, to create balanced distribution of services in the study area in order to eliminate disparities.
\end{abstract}

Keywords: Housing quality; neighbourhood quality; locational quality; infrastructural services; differentials; periurban settlements.

\section{INTRODUCTION}

Housing quality embodies not only the physical attributes and structural design of a building, but it also involves the neighbourhood prestige, locational quality, mobility control, user value and living convenience (Kain and Quigley, 1970). Housing quality is not limited to physical components of construction. It embraces human satisfaction with urban attributes and facilities, and entails the quality of the built environment, both in rural and urban areas (El Din et al., 2013). The quality of housing should satisfy minimum health standards, good living conditions and affordability for all categories of income earners (Amao, 2012). Housing quality is a function of geographical and ethnographic composition of the residents (Rapoport, 2001). There exists a varying degree of housing quality in the Lagos peripheral settlements due to many factors, among which some are resident-induced, while others arise as a result of state government's response to planning and infrastructure needs. In consonance with earlier findings by Allen (2010), a pronounced differential in environmental quality in Lagos peri-urban settlements in terms of disparity in distribution of public services should be addressed.

Three housing quality components as identified above are neighbourhood, locational and dwelling quality. Neighbourhood quality is attributed to the environment that a house is located in. This then brings into consideration the relationship between streets, open space and general settings in the neighbourhood (Rapoport, 1998). The quality of housing in peri-urban settlements is negatively affected by environmental factors like traffic congestion, lack of open space, pollution, inefficient water supply, poor sanitation and solid waste disposal management (Dutta, 2012). In addition, environmental quality has to do with cleanliness, sanitation, parking space, accessibility, light, drainage and security. Locational quality of housing is the spatial position

\footnotetext{
* Adedire Funmilayo Mokunfayo, Department of Architecture, Lead City University, Ibadan, Nigeria.

Email Correspondance: funmidire @ gmail.com

** Adegbile Michael, Department of Architecture, University of Lagos, Akoka, Lagos.
} 
occupied by the housing relative to the central business district. But, there is usually a gap in services delivery in African peri-urban settlements, which gives room to infiltration of irregular and high cost informal service providers (Chirisa, 2010; Allen, 2003). This is further emphasised by Simon (2008) that low housing density periurban settlements in developing countries is increasing commuting time due to poor condition of the roads.

Socio economic strength of the residents play a vital role in the type and level of housing quality that they can access. Household income level is significant for housing quality (Boamah, 2015). The poverty of urban poor undermines the quality of housing that they can enjoy. Housing quality is also, greatly influenced by socio-cultural setting (Fiadzo et al., 2001). The quality of peripheral settlements in Lagos is impaired by the great influx of low income urban immigrants (Lawanson et.al., 2012). Usually, the low income groups inhabit peri-urban areas which are prone to environmental hazards and lack good environmental quality (Allen, 2010). This however, is not the case in the districts or neighbourhood occupied by middle income earners or government-led housing in Lagos peripheral settlements, thus establishing social differentiation and service inequality among the indigenous residents and the immigrants (Simon, 2008; Ibem and Aduwo, 2015). Poor residential areas in most peri-urban settlements are associated with poor physical conditions, illegal development, limited or no access to water and poor sanitation (Fiadzo et, al., 2001).

Prior studies in Nigerian peripheral development have been limited to land use and linkages. None have captured the causes of the varying degree of housing quality in terms of the relationship between the three components of housing quality. To fill the gap in Nigerian housing research, this paper examines the causes and effects of differentials in housing quality in Lagos's peripheral settlements. With periurban settlements in Lagos accommodating a substantial size of urban population, it is vital to examine the challenges of housing quality not only for a sustainable built environment, but also to enhance the liveability of metropolitan peripheral areas and in turn ameliorate the impact of poor housing quality on residents' health and wellbeing. Therefore, the aim of this study is to examine the causes of differentials in housing quality in Lagos peripheral settlements and the overall effect on the people and the environment. Detailed studies in housing quality are needed to inform policy decisions in the emerging Nigerian new towns.

\section{LITERATURE REVIEW}

Indicators for measuring housing quality should embrace the physical characteristics of the dwelling and the broader environmental characteristics of the area under consideration (Cook and Bruin, 1994; Štreimikiene, 2014). Housing quality can be influenced by the building materials used, method of construction, poverty and land location. Critical also to housing quality is structural stability and durability, provision of basic services, good accessibility, security of tenure and limited crowdedness (Adebayo and Aliu, 2010). Further enumerated to contribute to housing quality are aesthetics, ornamentation, sanitation, drainage, age of building, access to basic housing facilities, burglary, spatial adequacy, noise level within the neighbourhood, sewage and waste disposal, air pollution and ease of movement (Anofojie et. al., 2014; Štreimikiene, 2014).

The quality conferred on a building as a result of internal and external designs is regarded as structural or dwelling quality. This is further emphasized by Amao (2012) stating that the role of spatial units and layout of the building play an important part in housing quality. Structural or dwelling quality is attributed to housing type, design, age of the building, aesthetics, lots size, windows, burglary proof and patio. It is generally believed to be influenced by income, family size, education and race (Goodman, 1978). Deficiencies of basic sanitary facilities, leaking roof and poorly lit buildings can also be used for assessment of dwelling quality. It also has to do with number of rooms per household, tiled toilet, tiled bath, tiled kitchen, light and water (Fiadzo, et. al., 2001). In addition, methods of construction, materials for construction, spatial arrangement, services and facilities functionality are also instrumental in defining the quality of a dwelling (Bradley and Putnick, 2012). Another major element of housing quality is population density, which is the availability of sufficient space in the dwelling both internally and externally (Štreimikiene, 2014). Space is associated with the overcrowding rate in a building and it can be measured by number of rooms per household, the household size and the family members' age (Aderamo and Ayobolu, 2010). Dwelling quality shows the intrinsic values of houses and it is typified by poor quality in developing countries (Aluko, 2010). 
Theoretically, factors that contribute to urban quality of life are physical urban quality, mobility urban quality of life, social urban quality psychological urban quality economical urban quality and political urban quality (El Din, et. al., 2013). Urban quality of life refers to the natural attributes of the neighbourhood, and it is the relationship that exists between different physical features of housing (Hamam et al. 2013). It entails the quality of the built environment both in rural and urban areas (Boamah, 2015). Neighbourhood quality is conferred on a residence as a result of the environment it is located in (Cook and Bruin, 1994; ElHadj, et. al., 2018). It focuses on the relationship between housing streets, open space and general settings in the neighbourhood (Rapoport, 1998).

Peri-urban settlements in developing countries are mostly associated with pollution of diverse kinds like refuse dumps and broken sewage plants thus imposing negative impact on the wellbeing of residents (Allen, 2003; Chirisa, 2010). Notable diseases with such environmental pollution in the African rural settlements are skin diseases, diarrhoea and Buruli ulcer (Boamah, 2012). Prior study by Boamah (2012) stated that housing conditions have an impact on the general and mental health of rural residents in Accra, Ghana. A study carried out on housing quality in peri-urban settlements in Akure, a Nigerian city, emphasized on the role of frequency of collection of waste on quality of housing in peripheral settlements. According to his findings, spread of an epidemic is prevalent with infrequent waste disposal (Anofojie, et.al., 2014)

Investigation by Allen (2003), identified categories of drinking water in most African peri-urban settlements as unimproved, improved and piped. Categories of toilet facilities were open defecation, unimproved, shared improved, shared toilet facilities. Unimproved category of drinking water includes pit latrines without slab or platforms, hanging latrines and bucket latrines. Shared improved toilets were flush toilet, flush latrines and ventilated improved pit (VIP). Categories of dwelling floor were divided between natural, rudimentary and finished flooring (Bradley and Putnick, 2012). Building materials in poor areas of the peripheral settlements included wood, reeds, grass for construction and roofing (Simon, 2008).

Locational quality of housing is the spatial position occupied relative to the central business district. Housing located close to facilities such as place of work, market, road, recreational facilities, schools, health facilities possesses higher locational benefits (Adebayo and Aliu, 2010). Good locational position brings ease in travel time to work and gives a higher satisfaction to residents (Cook and Bruin, 1994). Housing locational quality is also a function of accessibility to public transport. It is regarded as the living convenience and mobility control, which has to do with ease of commuting (Adebayo and Aliu, 2010). Housing location contributes to the socio-psychological development of children, and also affects the quality of education that can be accessed (Boamah, 2015). Furthermore, location of settlements is pivotal in the provision of employment and for support of services for housing (El-Hadj, et. al., 2018).

Housing quality cannot be discussed outside urban locational mobility. This brings to bear the influence of accessibility, traffic and transportation. In African peripheral settlements, there is high cost attached to daily travels and also slow traffic movement, because of the poor conditions of the access roads and the main arterial routes linking settlements (Lawanson et. al., 2012; Acheampong and Anokye, 2013). Commuting in peri-urban settlements of developing countries can often be burdensome. Poor transportation translates to road congestion, reduced productivity and lesse quality of life in the periphery of developing nations (Lawanson et. al., 2012). Therefore, locational quality refers to positional attributes while neighbourhood quality is associated with the extrinsic values of the neighbourhood (Aluko, 2010). The role of socio-economic and socio demographic attributes of residents cannot be overemphasized in the analysis of housing quality in transitioning towns like peri-urban settlements. Investigation by Allen $(2003,2010)$ shows that waste disposal is predominantly through landfill and incineration in the peri-urban areas. There exist indiscriminate disposal into canals and drainage channels (Puttal and Ravadi 2014). There is also pollution of water bodies by the toxic industrial waste, raw sewage and chemical affluent. According to Boamah (2012), the poorest households in most African peripheral settlements are subjected to these water sources which contributes to health hazards. In conclusion, the practice of building African urban and rural cities from back to front, that is, allowing spontaneous development before planning for services is the major cause of lack of basic social services like water, regular electricity, efficient sanitation services and transport systems (El-Hadj et. al., 2018).

\section{CONTEXT OF THE STUDY}

The selected cases for this study are Ibeju-Lekki and Ikorodu peri-urban settlements in Lagos State. Both are Local Government Areas in Lagos State, Nigeria (Figure 1). The two municipalities are outside the metropolitan region. It was decided to choose these areas because both regions 
have different dynamics of urbanism in terms of demographic composition, infrastructural development and locational potentials. While Ibeju-Lekki serves the housing needs of migrants from Lagos Island and its environment, Ikorodu absorbs people from Lagos Mainland and the surrounding. Also, Ibeju-Lekki represents the least urbanized peri-urban area in Lagos, in terms of population growth and housing development, while Ikorodu represents the highly urbanized peri-urban settlements in Lagos, in terms of residential development and population growth. Ibeju-Lekki Local Government Area has a land area of about 646 kilometres square, which equals to one quarter of the total land mass of Lagos state. According to the National Population Commission (2006) census, Ibeju-Lekki had a population of 117,481 out of Lagos State's total of 9,113,605. Ikorodu is located in the North East of Lagos State, along the Lagos lagoon and located at a distance of approximately $36 \mathrm{~km}$ north of Lagos. It occupies a land area of about 345 kilometres square. Ikorodu had an enumerated population of 535,619 in 2006 (National Population Commission and ICF Macro, 2009).

\section{METHODOLOGY}

This study employs a case study methodology based on a field survey. Case study approach was applied by conducting field research covering different types of housing development in the study areas. Primary data was sourced from the questionnaire instrument and on observation schedule through a field survey of the study areas. Two-stage cluster sampling technique was adopted in selecting the sample size which consisted of three hundred and seventy housing units in Ibeju-Lekki and three hundred and eighty four housing units in Ikorodu peripheral settlements. Housing types under selfbuilt, developer built and government housing were adequately represented in the sample size which was randomly selected from clusters of purposively selected sixteen settlements in Ibeju-Lekki and eighteen settlements in Ikorodu respectively. Purposive sampling was adopted to reduce costs and to eliminate repetition in responses. Six trained field personnel were engaged in the field survey that lasted for eight consecutive weekends. An approximate $98 \%$ and $98.6 \%$ return rates were achieved in Ibeju-Lekki and Ikorodu respectively. This was made possible by administering the questionnaires during non-working days and hours. Closed and open ended questions were administered to head of the selected households. The respondents answered questions on the socio- economic profile of household head which included gender, age, ethnicity, marital status, level of formal education, monthly household income, tenure and household size; internal dwelling quality, external quality, neighbourhood quality, accessibility to services and building materials used. Ethical considerations included consent from the management of gated housing estates and voluntary participation by respondents in the study area. Qualitative data included a structured interview with household heads and observation schedule used in studying the state of housing quality. Quantitative data for this study were extracted from the questionnaire responses. Descriptive analysis was conducted on the data to generate percentages and frequencies of responses on socio-economic profile of household heads,

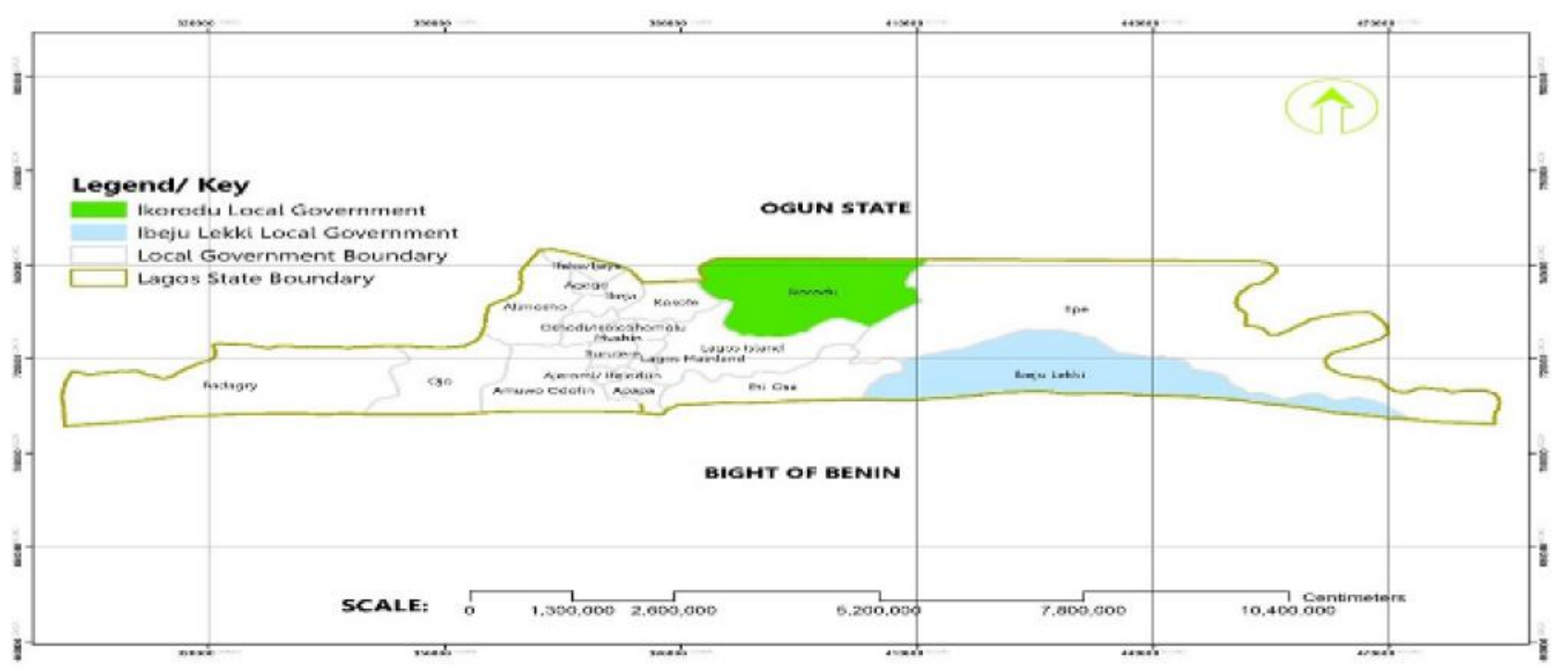

Figure 1: Map of Lagos showing Ibeju-Lekki and Ikorodu Source: Fieldwork, 2016. 
PRESENTATION OF RESULTS

Socio-Economic Profiles of the Respondents

Table 1: Household Heads' Socio-Economic Profile

\begin{tabular}{|c|c|c|c|c|c|}
\hline Variables & & $\begin{array}{l}\text { Ibeju-Lekki } \\
\mathrm{N}=366\end{array}$ & $\%$ & $\begin{array}{l}\text { Ikorodu } \\
\mathrm{N}=379\end{array}$ & $\%$ \\
\hline \multirow[t]{2}{*}{ Gender of Household Head } & Male & 223 & 60.9 & 244 & 64.4 \\
\hline & Female & 143 & 39.1 & 135 & 35.6 \\
\hline \multirow[t]{9}{*}{ Profession of Household Head } & Civil Service & 70 & 19.1 & 90 & 23.7 \\
\hline & Trading & 134 & 36.6 & 119 & 31.4 \\
\hline & $\begin{array}{l}\text { Professional } \\
\text { Practice }\end{array}$ & 61 & 16.7 & 56 & 14.8 \\
\hline & Unemployed & 2 & 0.5 & 3 & 0.8 \\
\hline & $\begin{array}{l}\text { Retired } \\
\text { Pensioner }\end{array}$ & 13 & 3.6 & 12 & 3.2 \\
\hline & Artisan & 56 & 15.3 & 67 & 17.7 \\
\hline & Student & 21 & 5.7 & 18 & 4.7 \\
\hline & Farming & 1 & 0.3 & 12 & 0.5 \\
\hline & Other & 8 & 2.1 & 2 & 0.5 \\
\hline \multirow[t]{6}{*}{ Literacy Level of Household Head } & Postgraduate & 56 & 15.3 & 25 & 6.6 \\
\hline & $\begin{array}{l}\text { BSc/Higher } \\
\text { Diploma }\end{array}$ & 105 & 28.7 & 124 & 32.7 \\
\hline & $\begin{array}{l}\text { National } \\
\text { Diploma }\end{array}$ & 62 & 16.9 & 79 & 20.8 \\
\hline & Secondary & 110 & 30.1 & 130 & 34.3 \\
\hline & Primary & 25 & 6.8 & 18 & 4.7 \\
\hline & None & 8 & 2.2 & 3 & 0.8 \\
\hline \multirow[t]{4}{*}{ Respondent's Ethnic Group } & Yoruba & 263 & 71.9 & 263 & 69.4 \\
\hline & Hausa & 6 & 1.6 & 13 & 3.4 \\
\hline & Ibo & 70 & 19.1 & 85 & 22.4 \\
\hline & Other & 27 & 7.4 & 18 & 4.7 \\
\hline \multirow[t]{3}{*}{ Monthly Incom Household Head } & Low Income & 133 & 36.6 & 150 & 39.6 \\
\hline & Middle Income & 70 & 19.1 & 178 & 46.9 \\
\hline & High Income & 163 & 44.6 & 51 & 13.4 \\
\hline \multirow[t]{5}{*}{ Household Size } & 1-2 Persons & 48 & 13.1 & 88 & 23.2 \\
\hline & 3-5 Persons & 202 & 55.2 & 185 & 48.8 \\
\hline & 6-9 Persons & 96 & 26.2 & 87 & 23 \\
\hline & 10-12 Persons & 8 & 2.2 & 14 & 3.7 \\
\hline & $\begin{array}{l}\text { More than } \\
13 \text { Persons }\end{array}$ & 12 & 3.3 & 5 & 1.3 \\
\hline \multirow[t]{4}{*}{ Tenure } & $\begin{array}{l}\text { Less than } \\
5 \text { years }\end{array}$ & 114 & 31.1 & 139 & 36.7 \\
\hline & 5-10 years & 116 & 31.7 & 142 & 37.5 \\
\hline & $\begin{array}{l}\text { More than } \\
10 \text { years }\end{array}$ & 134 & 36.6 & 97 & 25.6 \\
\hline & Other & 2 & 0.5 & 1 & 0.3 \\
\hline
\end{tabular}

Source: Field Survey (2016).

* Low income 25,000.00-50,000.00(\$70-\$140).

* Middle income 50,001.00-150,000.00(\$140-\$420).

* High income 150,001-above (\$420). 
access to services, and rating of neighbourhood quality, internal dwelling quality, external dwelling quality and building materials used in the study area. All statistical data analyses were performed using SPSS.

There were five recognised household sizes in the study areas as presented in Table 1. The commonest household sizes in both study areas were three to five persons. $55.2 \%$ of the households in Ibeju-Lekki and $48.8 \%$ household in Ikorodu had this household size. This was mostly common among the highly educated families and also the Yoruba ethnic group in the study areas. The least number of household size in the study areas was more than thirteen people which constituted $1.3 \%$ in Ikorodu and 3.3\% in Ibeju-Lekki. Male headed households were larger than female in both study areas. Informal trading was the commonest occupation in both study areas. This category of occupation had $36.6 \%$ in Ibeju-Lekki and $31.4 \%$ in Ikorodu. More people were engaged in civil service work in Ikorodu (23.7\%) than in Ibeju-Lekki (19.1\%). More residents were involved in professional practices in Ibeju-Lekki $(16.7 \%)$ than in Ikorodu $(14.8 \%)$. Farming was one of the least populated occupations in the two peri-urban settlements. Illiteracy level in both peri-urban settlements was very low. A high percentage of the population in both locations was literate, with only $6.8 \%$ and $4.7 \%$ respectively having primary education. The Yoruba ethnic group constituted the largest portion of the population in both peri-urban settlements, while the Hausa tribe was the least represented in the study areas. The predominant earning group of household head in Ibeju-Lekki was the high income, with average monthly earnings of $\mathrm{N} 150,000(\$ 420)$. This group constituted $44.6 \%$ while the low earning group, with monthly earnings of N25,000(\$70)$\mathrm{N} 50,000(\$ 140)$, constituted $36.3 \%$ and the middle income earning N50, 000(\$140) -N150,000 (\$420) constituted $19.1 \%$. However, in Ikorodu, the middle income group constituted $46.9 \%$ and was the highest. The low income group was $39.6 \%$ and the high income was $13.4 \%$. Analysis of tenure in the study areas showed that the maximum length of residence in both study areas was ten years.

\section{Internal dwelling quality in the study area}

The analysis in Table 2 shows the presence of good natural ventilation in both peri-urban settlements. Most buildings had cross ventilation aided by the availability of suitable openings and appropriate window sizes. Burglary protection system installation was high in both locations. Few houses

Table 2: Households' Internal Dwelling Quality.

\begin{tabular}{|c|c|c|c|c|c|}
\hline \multirow{2}{*}{ Variable } & & \multicolumn{2}{|c|}{ Ibeju-Lekki } & \multicolumn{2}{|c|}{ Ikorodu } \\
\hline & & $\mathrm{N}=366$ & $\%$ & 379 & $\%$ \\
\hline \multirow[t]{3}{*}{ Good Opening } & Yes & 339 & 92.6 & 334 & 88.1 \\
\hline & No & 27 & 7.4 & 44 & 11.6 \\
\hline & Neutral & 0 & 0 & 1 & 0.3 \\
\hline \multirow[t]{3}{*}{ Burglary Installation } & Yes & 314 & 85.8 & 309 & 81.5 \\
\hline & No & 51 & 13.9 & 69 & 18.2 \\
\hline & Neutral & 1 & 0.3 & 1 & 0.3 \\
\hline \multirow[t]{5}{*}{ Number of Rooms/Household } & $1-2 \mathrm{rm}$ & 193 & 52.7 & 218 & 57.5 \\
\hline & $3-4 \mathrm{rm}$ & 172 & 47 & 160 & 42.2 \\
\hline & Missing & 1 & 0.3 & 1 & 0.3 \\
\hline & 1 & 146 & 39.9 & 147 & 38.8 \\
\hline & 2 & 220 & 60.1 & 231 & 60.9 \\
\hline \multirow[t]{3}{*}{ Windows/Room } & Missing System & 0 & 0 & 1 & 0.3 \\
\hline & Flush & 297 & 81.1 & 317 & 83.6 \\
\hline & Pit Toilet & 69 & 18.9 & 61 & 16.1 \\
\hline \multirow[t]{2}{*}{ Toilet Type } & System & 0 & 0 & 1 & 0.3 \\
\hline & Yes & 264 & 72.1 & 281 & 74.1 \\
\hline \multirow[t]{2}{*}{ Tiled Kitchen } & No & 102 & 27.9 & 98 & 25.9 \\
\hline & Tap/Borehole & 272 & 74.3 & 322 & 85 \\
\hline \multirow[t]{2}{*}{ Source of Water } & Well/Others & 94 & 25.7 & 57 & 15 \\
\hline & Yes & 256 & 69.9 & 306 & 80.7 \\
\hline \multirow[t]{2}{*}{ Electricity Supply } & No & 110 & 30.1 & 72 & 19 \\
\hline & Missing System & 0 & 0 & 1 & 0.3 \\
\hline
\end{tabular}

Source: Field Survey (2016). 
lacked burglary protection systems. The commonest type of rooms per household were $1-2$ rooms, $52.7 \%$ and $57.5 \%$ in Ibeju-Lekki and Ikorodu respectively. $71.0 \%$ and $67.5 \%$ of respondent kitchens were tiled in Ibeju-Lekki and Ikorodu respectively. Flush toilet installation was generally seen in both locations despite of pits and other poor quality sanitary methods. $83.6 \%$ of the toilets were flush toilet systems with $72.1 \%$ of the toilets being tiled in Ibeju-Lekki. $83.6 \%$ of households had flush toilets and $74.1 \%$ of households had titled bathrooms in Ikorodu. The vast majority of peri-urban residents' in both locations relied on borehole water system, $74.3 \%$ in Ibeju-Lekki and $85 \%$ in Ikorodu. Other sources of water were wells and streams. Electricity supply in Ikorodu was better in Ibeju-Lekki. $80.7 \%$ of Ikorodu respondents had reliable supply of electricity from the grid and there was less reliance on alternative sources of electricity, thus reducing noise pollution.

\section{External dwelling quality}

Observation carried out on the selected housing units, showed generally high level of disrepair in both locations (Table 3). However, higher disrepair, in the form of dampness and tear was found in the buildings in Ikorodu $(61.6 \%)$ than in Ibeju-

Table 3: Households' Internal Dwelling Quality.

\begin{tabular}{|c|c|c|c|c|c|}
\hline \multirow{2}{*}{ Variable } & & \multicolumn{2}{|c|}{ Ibeju-Lekki } & \multicolumn{2}{|c|}{ Ikorodu } \\
\hline & & $\mathrm{N}=366$ & $\%$ & 379 & $\%$ \\
\hline & 0-5yesrs(Low) & 137 & 37.4 & 134 & 35.4 \\
\hline \multirow[t]{3}{*}{ State of Disrepair } & 5 above(High) & 229 & 62.6 & 245 & 64.6 \\
\hline & Good & 272 & 74.3 & 242 & 63.9 \\
\hline & Bad & 94 & 25.7 & 137 & 36.1 \\
\hline \multirow[t]{4}{*}{ State of Painting } & Total & 366 & 100 & 379 & 100 \\
\hline & Full & 307 & 83.9 & 279 & 73.6 \\
\hline & Not Full & 58 & 15.8 & 98 & 25.9 \\
\hline & Others & 1 & 0.3 & 1 & 0.3 \\
\hline \multirow[t]{2}{*}{ Lots Size } & Missing System & 0 & 0 & 1 & 0.3 \\
\hline & Modern Family House & 257 & 70.2 & 230 & 60.7 \\
\hline \multirow[t]{2}{*}{ Building Design } & Tenement House & 109 & 29.8 & 148 & 39.1 \\
\hline & Missing System & 0 & 0 & 1 & 0.3 \\
\hline
\end{tabular}

Source: Field Survey (2016).

Lekki (62.6\%). The state of painting showed a fairly regular exterior maintenance. More modern building designs existed in Ibeju-Lekki than in Ikorodu. This could be attributed to the presence of high income households in Ibeju-Lekki. Majority of the houses in both locations were built on standard full plots. A very good percentage of buildings in both locations had external paint, though some were in poor stare. There were reasonable number of modern housing present in both locations. But, tenement building designs were more prevalent in Ikorodu, especially those built for rental purposes.

According to the field survey analysis in Table 4, 30.6\% and $25.1 \%$ houses were affected by noise pollution in IbejuLekki and Ikorodu peri-urban settlements respectively. 66.4\% of the housing units in Ibeju-Lekki lacked good drainage in comparison to $80.2 \%$ in Ikorodu. $66.9 \%$ households in Ibeju-Lekki had access to good waste disposal system, while only $26.4 \%$ signified the availability of an efficient waste management system in Ikorodu. The greater proportion of the residential areas, $61.7 \%$ in Ibeju-Lekki and $79.9 \%$ of Ikorodu, did not have good roads. Environmental security in Ikorodu was $44.1 \%$ and $71 \%$ in Ibeju-Lekki.

\section{Respondents' access to services}

The survey analysis in Table 5 indicates that in Ibeju-Lekki, a greater percentage of the sampled population enjoys locational proximity to their places of work. $85.8 \%$ of the respondents had good proximity in comparison to $72.8 \%$ in Ikorodu. Locational proximity to the central business district was an advantage in both study locations. $86.1 \%$ of the household heads in Ibeju-lekki and $72.0 \%$ in Ikorodu periurban were seen to be close to the central business districts. The percentage of the population lacking health facility was less in Ibeju-Lekki as compared to Ikorodu (48.8\%). Availability of school was not a critical issue in Ibeju-Lekki. 94.3\% households showed satisfaction with the provision of schools but only $61.5 \%$ of households in Ikorodu showed satisfaction with access to school. About $22.1 \%$ of households saw lack of public transport as a locational deficiency in Ibeju-Lekki as against $15.6 \%$ in Ikorodu peri-urban settlement. 


\section{Respondent's Rating of Neighourhood Quality}

Table 4: Respondent's of Rating of Neighbourhood Quality.

\begin{tabular}{|c|c|c|c|c|c|}
\hline \multirow{2}{*}{ Variable } & & \multicolumn{2}{|c|}{ Ibeju-Lekki } & \multicolumn{2}{|c|}{ Ikorodu } \\
\hline & & $\mathrm{N}=366$ & $\%$ & 379 & $\%$ \\
\hline & Yes & 112 & 30.6 & 95 & 25.1 \\
\hline & No & 250 & 68.3 & 277 & 73.1 \\
\hline & Neutral & 4 & 1.1 & 4 & 1.1 \\
\hline & Missing & & & & \\
\hline \multirow[t]{4}{*}{ Noise Polluton } & System & 0 & 0 & 2 & 0.5 \\
\hline & Yes & 119 & 32.5 & 70 & 18.5 \\
\hline & No & 243 & 66.4 & 304 & 80.2 \\
\hline & Neutral & 4 & 1.1 & 2 & 0.6 \\
\hline \multirow[t]{4}{*}{ Good Drainage System } & Missing & 0 & 0 & 2 & 0.5 \\
\hline & Yes & 245 & 66.9 & 100 & 26.4 \\
\hline & No & 121 & 33.1 & 276 & 72.8 \\
\hline & Missing & & & & \\
\hline \multirow[t]{3}{*}{ Good Waste Disposal } & System & 0 & 0 & 2 & 0.5 \\
\hline & Yes & 140 & 38.3 & 74 & 19.5 \\
\hline & No & 226 & 61.7 & 303 & 79.9 \\
\hline \multirow[t]{2}{*}{ Good Road } & System & 0 & 0 & 1 & 0.3 \\
\hline & Yes & 260 & 71 & 167 & 44.1 \\
\hline \multirow[t]{2}{*}{ Environmental Security } & No & 103 & 28.1 & 211 & 55.7 \\
\hline & System & 3 & 0.8 & 1 & 0.3 \\
\hline
\end{tabular}

Source: Field Survey (2016).

There was generally a reasonable level of internal dwelling quality in both study areas. This could be seen by the higher number of households with tiled kitchen, bathroom, flush toilet and accessibility to borehole or tap water. However, external dwelling quality varied in each study area. Though, there existed a high level of disrepair in both study areas, observation showed that most disrepair was basically associated with poor maintenance and to the age of buildings as confirmed from the respondents. Buildings with high disrepair were mostly aged above five years. The finding also showed dampness to be an additional cause of external wall tears in Ibeju-Lekki, because of the surrounding coastal landscape. It is worthy to state that more disrepair was noted in low income households than in the middle and high income groups. This corroborates Cook and Bruin (1994) findings on the impact of poverty inter alia housing maintenance and quality.

In terms of neighbourhood quality, the lack of suitable drainage system contributed greatly to floods, thus causing vehicular congestion, especially during the rainy season in the study areas. Associated problems with this challenge were high commuting time and reduced productivity for the households in Lagos peri-urban settlements. Waste disposal management was a huge burden for peri-urban residents in
Ikorodu peri-urban settlements. Further more, poorer waste management in this study area in comparison to Ibeju-lekki can be attributed to more self-built housing in the former. Most low income households rely on the use of participative community services to tackle waste disposal and this is often ineffective. Implications of poor waste management include the spread of diseases and endangered human health in affected Lagos peri-urban settlements (Lawanson, Yadua and Salako, 2012; Boamah, 2015).

Noise pollution was less of an influential neighbourhood challenge in the study area. But, this was minimal in both study areas. Observation during the field work also showed that residential areas close to manufacturing companies were more prone to noise pollution.

The high level (55.7\%) of environmental security in Ikorodu peri-urban settlements could be attributed to the socioeconomic class of the households. Most houses were not gated and hence prone to robbery and burglary attacks in Ikorodu.

Both locations had good locational proximity to the CBD. But, the presence of government institutions in Ikorodu were a boost for better public transportation system as 
Table 5: Respondents' Access to Services.

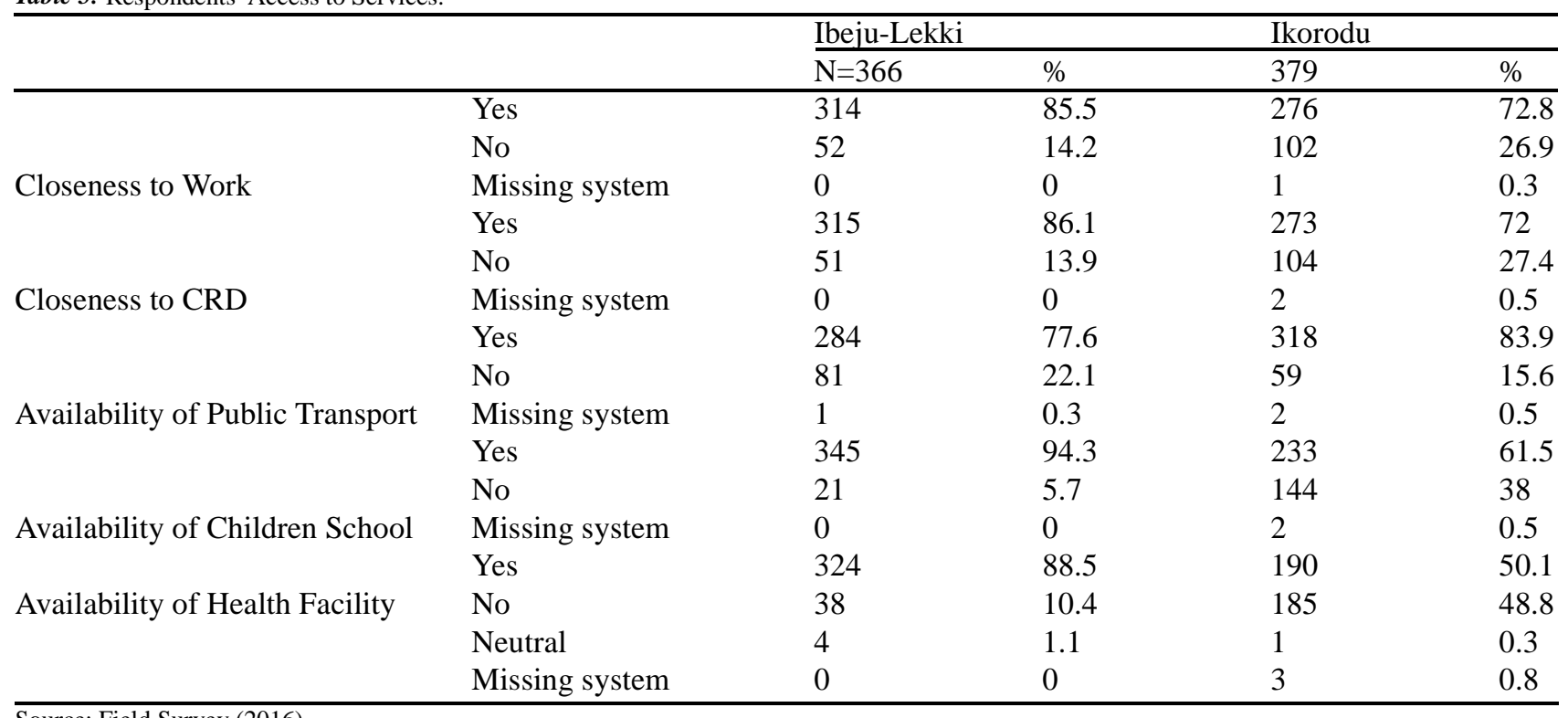

Source: Field Survey (2016).

\section{Assesment of Building Materials Used.}

Table 6: Building Materials Used.

\begin{tabular}{|c|c|c|c|c|c|}
\hline & & Ibeju-L & & Ikor & \\
\hline & & $\mathrm{N}=366$ & $\%$ & 379 & $\%$ \\
\hline & Block wall & 342 & 94.4 & 316 & 83.3 \\
\hline & Mud wall & 13 & 3.55 & 51 & 13.4 \\
\hline & Thatch/others & 7 & 1.9 & 11 & 2.9 \\
\hline Wall & Missing System & 4 & 1.1 & 1 & 0.3 \\
\hline & Aluminium & 277 & 75.7 & 223 & 58.8 \\
\hline & Thatch & 20 & 5.5 & 62 & 16.4 \\
\hline & Concrete slab & 23 & 6.3 & 47 & 12.4 \\
\hline & Other & 46 & 12.6 & 46 & 12.1 \\
\hline Roof & Missing system & 0 & 0 & 1 & 0.3 \\
\hline & Aluminium & 251 & 68.6 & 243 & 64.1 \\
\hline & Louvre & 37 & 10.1 & 74 & 19.5 \\
\hline & Wooden & 47 & 12.8 & 56 & 14.8 \\
\hline & Casement & 31 & 8.5 & 5 & 1.3 \\
\hline Window & Missing system & 0 & 0 & 1 & 0.3 \\
\hline & Steels/iron & 130 & 35.5 & 170 & 44.9 \\
\hline & Flush/panel/wooden & 229 & 62.6 & 176 & 46.4 \\
\hline & Glass & 2 & 0.5 & 24 & 6.3 \\
\hline & Others & 5 & 1.4 & 8 & 2.1 \\
\hline Door & Missing System & 0 & 0 & 1 & 0.3 \\
\hline
\end{tabular}

Source: Field Survey (2016) 
compared to Ibeju-Lekki. High cost of transportation forzthose without personal vehicles in the latter was a result of limited public transportation facilities. In Ikorodu, the good distribution of government organisations and strategic locations of most institutions close to both primary and secondary roads made it easier for peri-urban residents to access their work places.

More households lacked health facilities, more in Ikorodu than in Ibeju-Lekki, which showed a more improved infrastructure development and hence better quality of life. Settlements further away from the city centre lacked medical facilities because of the cost implication of locating such facilities in areas where housing density is low.

A higher percentage of households showed dissatisfaction with the provision of primary school in Ikorodu as competed to Ibeju-Lekki. This could be attributed to the locational preference of private education providers, as they are strategically located where their services can be rewarded by high income groups. Low income group in peri-urban settlements could not afford the high service charges attached to private education in Lagos. Reliance of most low income group in Lagos peri-urban was on public schools, and these were limited in relation to the peri-urban population of school age children.

There was no significant difference in the use of building materials in Ibeju-Lekki and Ikorodu. However, majority of the households had adopted conventional building materials like cement sandcrete blocks, aluminium burglary proof windows, mostly wooden panel internal doors and steel external doors. The use of louvred and wooden windows in both locations was limited. Aluminium roofing was common in both peri-urban settlements of Ibeju-Lekki and Ikorodu. Thatch roof (sun dried palm fronts) wall was sparingly used in areas belonging to natives, whose primary occupation was fishing and coconut farming.

\section{CONCLUSION}

Housing quality cannot be examined in isolation without putting into consideration the three variables factored in this research work, neighbourhood quality, locational quality and dwelling quality. To corroborate the findings of El-Hadj, Faye and Geh (2018), government disparity in infrastructure development or the back to front system adopted where intervention is needed has impacted greatly on poor neighbourhood, locational quality and provision of basic social amenities in most peri-urban housing developments in Lagos State. Regarding government and private developer housing, concentration has been more on dwelling and neighbourhood quality, creating poor user performance in such housing in Lagos peri-urban settlements.

Also, most government housing initiative lack good locational quality because of the intentional policy of residential segregation from poor neighbourhoods in Lagos peri-urban settlements. Government disparity in infrastructure development has impacted the poor neighbourhood and locational quality of most of the periurban housing developments. Therefore, planning of housing schemes in Lagos peri-urban settlements should be integrated with other urban land uses, for efficient distribution of infrastructural facilities. Furthermore, post occupancy study should be carried out in government and private housing development to determine their efficiency and suitability for households in the peri-urban settlements. This will enhance performance standard in other housing projects to be carried out.

Both government-led and developer-led housings rely much on the use of conventional building materials. The research findings show no trace of alternative building materials for the mentioned housing initiatives in Lagos peri-urban settlements. Advocacy for housing policy that promotes the use of alternative building materials by the government and private developers will aid housing affordability and accessibility for the low income group and would lead to improved quality of housing in Lagos peri-urban settlements. This would also help in reducing poor quality self-built housing. It can be concluded that there exist differentials in housing quality in Lagos peri-urban settlements and this is influenced mostly by socio-economic capacity of households, mostly income, type of housing initiatives and the state government subtle policy of residential segregation by income, class and education.

\section{RECOMMENDATION}

To improve housing quality among the low income group, the state government should intervene in the housing process of self-built housing development, in terms of disseminating education on spatial adequacy, dwelling quality and suitability of construction materials to be used. There should be a policy review regarding balanced infrastructure development to minimise differentials in housing quality due to residential segregation in Lagos peri-urban settlements. Furthermore, updated demographic data is relevant for policies regarding the provision of infrastructure and relevant complementary facilities needed to promote housing quality in Lagos peri-urban settlements. 


\section{REFERENCE}

Acheampong, R. A. and Anokye, P. A., 2013, “Understanding Households' Residential Location Choice in Kumasi's PeriUrban Settlements and the Implications for Sustainable Urban Growth", Research on Humanities and Social Sciences, 3(9), 60-70.

Adebayo, I. and Aliu, A., 2010, “Evaluating The Influence Of Housing Quality On Urban Residents' Wellbeing: The Case Of Lagos Nigeria”, International Journal of Academic Research, 2(6), 401-410.

Aderamo, A. and Ayobolu, D., 2010, “Spatial Structure of Housing Quality in Ilorin, Nigeria”. Research Journal of Social Sciences, 1(5), 12-21.

Allen, A., 2003, "Environmental Planning and Management of the Peri-Urban Interface: Perspectives on an Emerging Field". Journal of Environmentand Urbanization, 15(1), 135-147.

Allen, A., 2010, Neither Rural nor Urban: Service Delivery Options That Work for the Peri-urban Poor, University College London, Environment and Sustainable Development (ESD), London: University College London.

Aluko, O., 2010, “The Impact of Urbanization on Housing Development: The Lagos Experience, Nigeria”. Ethiopian Journal of Environmental Studies and Management, 3(3), 64-74.

Amao, F. L., 2012, “Urbanization, Housing Quality and Environmental Degeneration in Nigeria”, Journal of Geography and Regional Planning, 5(16).

Anofojie, A. E., Adeleye, O. A. and Kadiri, M. A., 2014, "Housing Quality Assessment In Selected Public Residential Estates in Amuwo-Odofin L.G.A, Lagos, Nigeria”, International Journal of Research In Earth and Environmental Sciences, 2(6), 7-17.

Boamah, N., 2012, "Housing for the Vulnerable in the Offinso South Municipality of Ghana", Housing, Care and Support, $15(3), 140-147$.

Boamah, N., 2015, "The Impact of Households Characteristics on the State of Housing in the Offinso South Municipality (OSM),Ghana. Environment, Development and Sustainability, 17(6),1251-1266.

Bradley, R. H., and Putnick, D. L., 2012, "Housing Quality and Access to Material and Learning Resources within the Home Environment in Developing Countries", Child Development, 83(1), 76-91.

Chirisa, I., 2010, "Peri-Urban Dynamics and Regional Planning in Africa: Implications for Building Healthy Citie", Journal of African Studies and Development, 2(2), 15-26.

Cook, C. and Bruin, M. J., 1994, "Determinants of Housing Quality: A Comparison of White, African-American and Hispanic Single-Parent Women”, Journal of Family and Economic Issues, 15(4), 329-347.

Dutta, V., 2012, "Land Use Dynamics and Peri-urban Growth Characteristics: Reflections on Master Plan and Urban Suitability from a Sprawling North Indian City”, Journal of Environment and Urbanization ASIA, 3(2), $277-301$.

El Din, H. S., Shalaby, A., Farouh, H. E. and Elariane, S. A., 2013, "Principles of Urban Quality of Life for a Neighborhood", Housing and Building National Research Center, 9(1), 86-92.

El-Hadj, M., Faye, I. and Geh, Z., 2018, The Political Economy of Housing Development in Africa. In Housing Market Dynamics in Africa. Palgrave Macmillan, London.

Fiadzo, E. D., Houston, J. E. and Godwin, D. D., 2001, "Estimating Housing Quality for Poverty and Development Policy Analysis: CWIQ in Ghana”, Social Indicators Research, 53(2), 137-162.

Goodman, J. L 1978, “Causes and Indicators of Housing Quality”, Social Indicators Research, 5(2), 195-210.

Hamam, S. E., Ahmed, S. and Hend, E. F., 2013, "Principles of Urban Quality of Life for a Neighborhood”, Journal of Housing and Building National Research Center, 9(1), 86-92.

Ibem, E. O. and Aduwo, E. B., 2015, “Assessment of the Sustainability of Public Housing Projects in Ogun State, Nigeria: 
A Post Occupancy Evaluation Approach", Mediterranean Journal of Social Sciences, 6(2), 523-536.

Kain, J. F. and Quigley, J. M., 1970, "Measuring the Value of Housing Quality", Journal of the American Statistical Association, 65(330), 532-548.

Lawanson, T., Yadua, O. and Salako, I. (2012). “An Investigation of Rural-Urban Linkages of the Lagos Megacity, Nigeria”. Journal of Construction Project Management and Innovation., 2(2), 464-581.

Puttal, V. and Ravadi, N. 2014, "Role of Urban Planning as Tool to Mitigate the Environmental Repercussions Due To Peri-urbanisation", Journal of Civil Engineering and Environmental Technology, 1(3), 96-102.

Rapoport, A., 1998, "Using "culture" in Housing Design”, Journal of Housing and Society, 2(25(1and2)), 1-20.

Simon, D., 2008, “Urban Environments: Issues on the Peri-Urban Fringe”, Annual Review Environmental Resources, 33, 167-185.

Štreimikiene, D., 2014, “Housing Indicators For Assessing Quality Of Life In Lithunia”, Intellectual Economics, 8(1), 25-41. 